\title{
METÁN A LÉGKÖRBEN
}

\section{METHANE IN THE ATMOSPHERE}

\author{
Haszpra László \\ az MTA doktora \\ Országos Meteorológiai Szolgálat, MTA Csillagászati és Földtudományi Kutatóközpont \\ haszpra.l@met.hu
}

\begin{abstract}
ÖSSZEFOGLALÁS
Bár a metán a második legfontosabb üvegházhatású gáz a légkörben, melynek mennyiségére az emberi tevékenység közvetlenül hatást gyakorol, forrásait, nyelőit és légköri folyamatait csak jelentős bizonytalansággal ismerjük. Légköri koncentrációja az ipari forradalom kezdetétől az 1990-es évek végéig folyamatosan emelkedett, ezt követően azonban egy időre a növekedés lényegében leállt. 2007-től, csaknem egy évtizednyi szünet után a koncentráció ismét meredek növekedésnek indult. A jelenségre egyelőre nincs általánosan elfogadott magyarázat. A tanulmány jelenlegi tudásunk alapján tekinti át a metán forrásait, nyelőit és légköri folyamatait, továbbá a tapasztalt koncentrációváltozások lehetséges magyarázatait.
\end{abstract}

\section{ABSTRACT}

Despite methane being the second most important greenhouse gas in the atmosphere directly influenced by the anthropogenic activity, its sources, sinks and processes are known only with significant uncertainty. Its atmospheric concentration had increased from the beginning of the Industrial Revolution until the late 1990s, when it virtually stopped. The steep increase in the concentration resumed after a decade of pause, in 2007. There is no generally accepted explanation for the phenomenon yet. The paper reviews the sources, sinks and processes of atmospheric methane, as we know them today, furthermore the potential explanations for the strange concentration course observed.

Kulcsszavak: légkör, metán, éghajlatváltozás, üvegházhatás, koncentrációváltozás, stabilizotóp-összetétel

Keywords: atmosphere, methane, climate change, greenhouse effect, concentration change, stable isotope composition 
Az ezüst is szépen csillog, szoktuk mondani, leplezve, hogy nem becsüljük érdemük szerint a második helyezést elérő versenyzőket. Nincs ez másképp az üvegházhatású gázok esetében sem. E téren az emberi tevékenység által közvetlenül befolyásolt gázok között, a Föld éghajlatát meghatározó energiamérlegre gyakorolt hatás alapján a metán $\left(\mathrm{CH}_{4}\right)$ a második legfontosabb. Ha van a gázoknak önérzetük, akkor a metánét bizonyára sérti, hogy kibocsátását, légköri menynyiségét és éghajlati hatását is sokszor az első helyezetthez, a szén-dioxidhoz viszonyítva, szén-dioxid-egyenértékben adják meg. Pedig a metán, különösen a globális éghajlatváltozás jelenlegi tendenciája mellett, a jövőben egyre fontosabb szerepet játszhat a légkörben, miközben forrásait, nyelőit, a légköri mennyiségét szabályzó folyamatokat, mindezek éghajlati érzékenységét egyelőre aggasztóan kevéssé ismerjük.

\section{A LÉGKÖRI METÁN FORRÁSAIÉS NYELŐI}

A metán felfedezése Alessandro Volta nevéhez füződik, aki 1777-ben a mocsarakból feltörő légbuborékokban éghető gázt azonosított (URL1). A jelenségből, mai szemmel nézve, következtethettek volna arra, hogy a metán a levegőben is megtalálható. E felismerés hiányában azonban a metán légköri jelenlétének felfedezését általában Marcel Migeotte nevéhez kötik, aki 1948-ban a légkörön áthatoló napsugárzás infravörös spektrumát elemezve bukkant a metánra (Migeotte, 1948).

Földi viszonyok között a metán képződése elsősorban a szerves anyagok átalakulásához kapcsolódik. A metán nagy része a felszínen, illetve a felszín közelében biológiai folyamatok révén keletkezik, de jelentős a földkéregben termikus folyamatokban, illetve az égési folyamatok (elsősorban biomasszaégés/égetés) során keletkező mennyiség is. A képződés módjától függően más a keletkező metán stabilizotóp-összetétele, ${ }^{13} \mathrm{C} /{ }^{12} \mathrm{C}$, illetve ${ }^{2} \mathrm{H} /{ }^{1} \mathrm{H}$ aránya (Quay et al., 1999; Monteil et al., 2011). A különböző biológiai forrásokból kikerülő metán ${ }^{13} \mathrm{C} /{ }^{12} \mathrm{C}$, illetve ${ }^{2} \mathrm{H} /{ }^{1} \mathrm{H}$ aránya jellemzően alacsonyabb, mint a fosszilis forrásokból származóé. A légköri metán stabilizotóp-összetételének változása a különböző metánforrások hozzájárulási hozamának, egymáshoz viszonyított arányának változására utal.

A légkörbe kerülő metán meghatározó része a szerves anyagok anaerob bomlása során keletkezik. Ez a folyamat a természetben elsősorban a mocsaras, lápos, tőzeges, szerves anyagokban gazdag vizenyős területeken zajlik, ahonnan a rendelkezésre álló közvetlen mérések alapján 185 [153-227] $\operatorname{Tg}^{1}$ metán kerül évente a levegőbe. Nem sokkal kisebb hozamú forrást jelentenek az édesvízzel

${ }^{1} 1 \mathrm{Tg}$ (teragramm) $=10^{12} \mathrm{~g}=1$ millió tonna. A szögletes zárójelben lévő tartomány a mérések alapján végzett becslések minimumát és maximumát jelzi. 
tartósan borított területek, a folyók és tavak (122 [60-180] Tg $\left.\mathrm{CH}_{4} / \mathrm{év}\right)$. A biológiai források között említést érdemelnek még a vadon élö állatok, elsősorban a kérődzők és a termeszek, amelyek emésztőrendszerében képződik metán, évente 19 [8-30] Tg-nyi mennyiségben. A geológiai források (geotermikus területek, szivárgások, metánhidrát) éves átlagban 55 [35-76] Tg metánt bocsáthatnak a légkörbe. Az erdő- és bozóttüzekböl, valamint az egyéb forrásokból származó metán mennyisége a már felsorolt tételekhez képest csekély. A 2003-2012 közötti időszakra a természetes metánkibocsátást összességében 384 [257-524] Tg/év értékünek becslik a feltételezett forráshozamok alapján.

Emberi tevékenység révén is kerül metán a levegőbe, ugyancsak elsősorban biológiai folyamatok során. Ezen kategórián belül a legnagyobb tételt az állattenyésztés jelenti (106 [97-111] Tg $\mathrm{CH}_{4} / \mathrm{e} v$ ), beleértve mind az emésztéshez, mind a trágyakezeléshez kapcsolódó kibocsátást. A szennyvíz és a szilárd szerves hulladék bomlása 59 [52-63] Tg-mal járul hozzá az évi globális metánkibocsátáshoz. A rizsföldek, ahol a mocsarakéhoz hasonló folyamatok zajlanak, 30 [24-36] Tg metánt bocsátanak ki évente. A biomassza közvetlen vagy bioüzemanyagként való elégetésének hozama 30 [27-35] Tg/év. A fosszilis tüzelőanyagokhoz kapcsolódó kibocsátás (szénbányászat, olaj- és gázipar, a fosszilis tüzelőanyagok szállítása és tökéletlen égetése stb.) ennél lényegesen több, évi 121 [114-133] Tg metánt juttat a levegőbe. A forráshozamok alapján a 2003-2012 közötti időszakra becsülhetö átlagos globális antropogén metánkibocsátás együttesen 352 [340-360] Tg/év lehetett.

A légkörbe került metán csekély részét (33 [28-38] Tg/év) a metanotróf baktériumok felveszik. A metán nagy részét azonban a kémiai folyamatok távolítják el a légkörből, elsősorban $(\sim 90 \%)$ a hidroxil-gyökkel $(\mathrm{OH})$ való reakció. A keletkező peroxi-gyökök révén a metán az éghajlat közvetlen alakításán kívül fontos szerepet játszik a troposzferikus ózonképződésben is, míg a sztratoszférában a végtermékként képződő vízgőznek van jelentősége. Mind az ózon, mind a vízgőz a metánhoz hasonlóan üvegházhatású gáz. A metánmolekulák átlagos légköri tartózkodási ideje körülbelül kilenc év.

A fenti adatok Marielle Saunois és nyolcvan szerzőtársának nagy lélegzetü összefoglaló munkájából származnak (Saunois et al., 2016), amely jelenleg a legfrissebb, legalaposabb tanulmány ezen a területen. A forráshozamok a befektetett hatalmas munka ellenére is meglehetösen bizonytalanok, és egyes tételekben nem kis mértékben térnek el egymástól a különböző korábbi becslések is. A becslések széles tartományának legfőbb oka, hogy a kutatók jobb híján korlátos számú helyen, korlátozott ideig végzett metánkibocsátás-mérésből próbálnak következtetni a globális kibocsátásra. Néhány mocsaras területen végzett mérésből kell becslést adni a világ összes, különböző anyagi és éghajlati jellemzőjü mocsarának teljes kibocsátására, ami igen nagy bizonytalanságot rejt. Hasonló a helyzet a többi forráskategóriával is. 
A légkörkutatók elvileg javíthatják e becslések pontosságát. A méröállomásokon mért légköri metánkoncentrációk különbségéből, térbeli és időbeli változásából a légköri terjedési és átkeveredési viszonyok ismeretében az ún. inverz terjedési modellek segítségével becsülhető, hogy hol és mennyi metán került a levegőbe (lásd például Kirschke et al., 2013; Houweling et al., 2017; Bergamaschi et al., 2018). A módszer nem tud az egyes forráskategóriákra adatot szolgáltatni, csak a források földrajzi lokalizációjára képes. Saunois és munkatársai az inverz modellek eredményeit is áttekintették. Míg a forráshozamokból becsült (ún. bottom-up közelítés) természetes kibocsátás 384 [257-524] Tg/év-nek adódott (lásd fenn), addig a légköri mérésekböl (ún. top-down közelítés) számolt érték 231 [194-296] Tg/év. Bár a bizonytalansági tartományok átfednek, a különbség meglehetősen nagy. Az emberi eredetü kibocsátás globális összegét a forráshozamok oldaláról is viszonylag pontosan becsülni tudjuk, és a kapott értéktől a top-down megközelítés sem tér el lényegesen (328 [259-370] Tg/év). A légkörkutatók általában a teljes légkörre vonatkozó mérésekből visszaszámolt globális forráserősséget hitelesebbnek tartják, mint az eseti mérésekből „felskálázottat”, de a mérési pontok csekély száma és a számítások elvégezhetőségéhez elkerülhetetlenül szükséges feltevések ezeket az adatokat is meglehetősen bizonytalanná teszik.

\section{A METÁN LÉGKÖRI KONCENTRÁCIÓJÁNAK ALAKULÁSA}

Az éghajlatváltozással kapcsolatban többnyire az üvegházhatású gázok emberi kibocsátásáról esik szó, holott a Föld-légkör rendszer energiamérlege nem a kibocsátástól, hanem az adott gáz légköri mennyiségétől függ. Ennek kialakításában pedig az éghajlati viszonyokra érzékenyen reagáló természetes források és nyelők ugyancsak fontos szerepet játszanak. Az antarktiszi jég légzárványainak elemzéséből körülbelül 800 ezer évre visszamenően ismerjük a metán légköri mennyiségét. A holocént megelőző időszakban koncentrációja (szabatosabban: vízmentes levegőre vonatkozó mól-aránya) jellemzően 350 és 700 nmol/mol között ingadozott ${ }^{2}$ (Loulergue et al., 2008), összhangban a glaciálisok és interglaciálisok váltakozásával. Mivel a metán döntő része biológiai folyamatok eredménye, alacsonyabb hőmérséklet mellett kevesebb került a levegőbe; a kevésbé hőmérsékletfüggő nyelö folyamatok mellett alacsonyabb egyensúlyi koncentráció ala-

${ }^{2}$ A földi légkörben a metán ideális gázként viselkedik, ezért a levegőre vonatkozó mól-aránya és a mennyiségének jellemzésére gyakran használt térfogataránya számszerüleg megegyezik. A térfogatarányra gyakran használt mértékegységek (ppm, ppb stb.) azonban nem illeszkednek az SI-mértékegység-rendszerhez, ezért használatuk a szakirodalomban visszaszorulóban van. 
kult ki. A csökkenő metánkoncentráció, az ennek révén is gyengülő üvegházhatás pozitív visszacsatolásként erősített rá az egyébként is folyamatban lévő lehülésre. A legutóbbi jégkorszakot követően, nagyjából ötezer évvel ezelőtt kezdődött meg a metánkoncentráció kisebb átmeneti visszaesésektől (például kis jégkorszak) eltekintve egyenletes emelkedése, körülbelül $550 \mathrm{nmol} / \mathrm{mol}-$ ról. Ebben az emelkedésben a stabilizotóp-összetételre vonatkozó adatok szerint a biológiai források játszották a főszerepet, de jelenlegi ismereteink alapján az nem eldönthető, hogy mekkora része volt az emberi tevékenységnek, az állattenyésztés kialakulásának, a rizstermelés megjelenésének, általában véve az emberiség lélekszámával növekvő élelmiszer- és szerveshulladék-termelésnek, illetve a természeti folyamatoknak (Sapart et al., 2012). A 18. század közepére, az ipari forradalom kezdetére a metánkoncentráció $720 \mathrm{nmol} / \mathrm{mol}-\mathrm{ra}$ emelkedett, innentöl viszont egyre gyorsuló növekedést látunk (1. ábra). Ez a gyors növekedés döntő részben a légkörbe kerülő fosszilis eredetű metánnak volt köszönhető, miközben a növekvő élelmiszer-szükséglet és hulladékképződés miatt az emberi tevékenységhez kötődő biológiai eredetủ metánkibocsátás is nőtt.

Közvetlen légköri koncentrációmérések az 1980-as évek elejétől állnak rendelkezésünkre. Ezek elegendően pontosak ahhoz, hogy a légkör teljes metántartalmát, ennek évek közötti változását $<5 \mathrm{Tg}$ bizonytalansággal becsüljük. Az 1980-as évek elején a koncentráció évenként 10 nmol/mol-t meghaladó mérték-

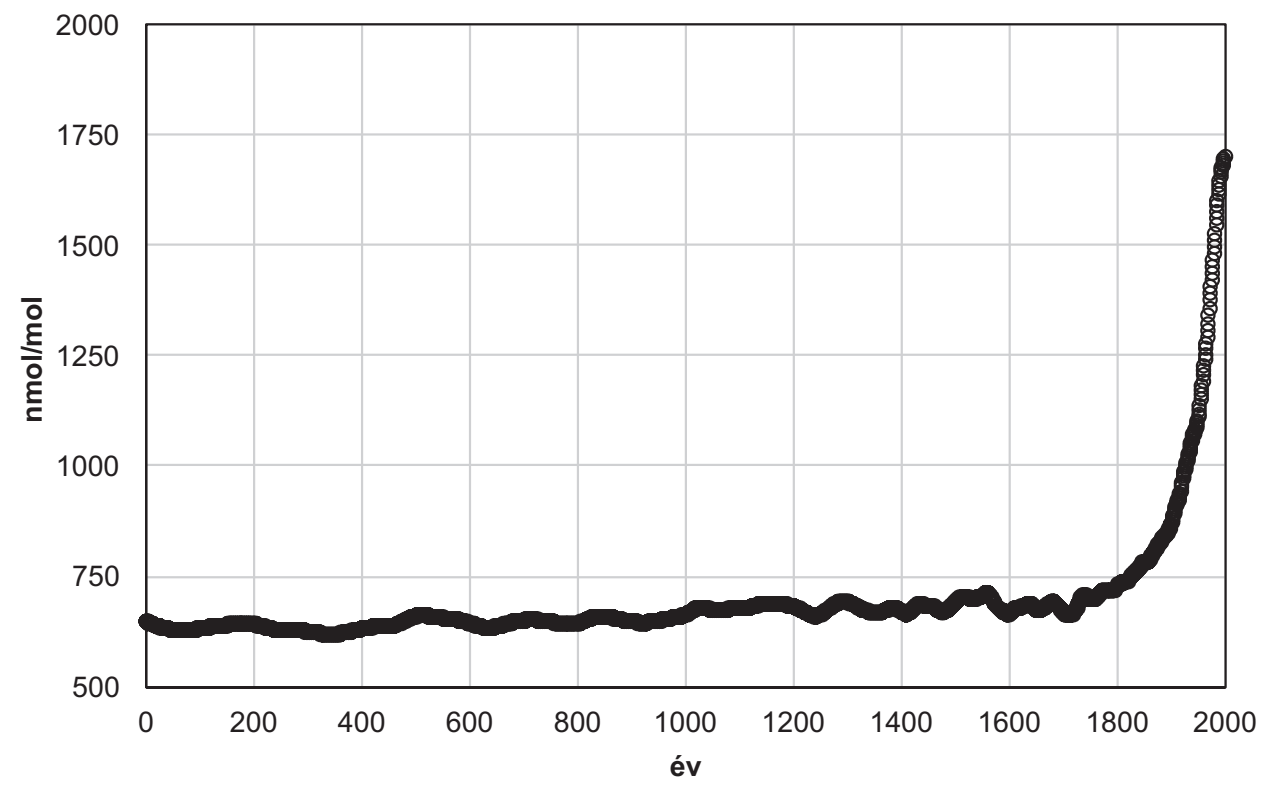

1. ábra. A légkör metánkoncentrációjának alakulása az Antarktisz felett időszámításunk kezdetétől 2000-ig (Ferretti et al., 2005; URL2) 


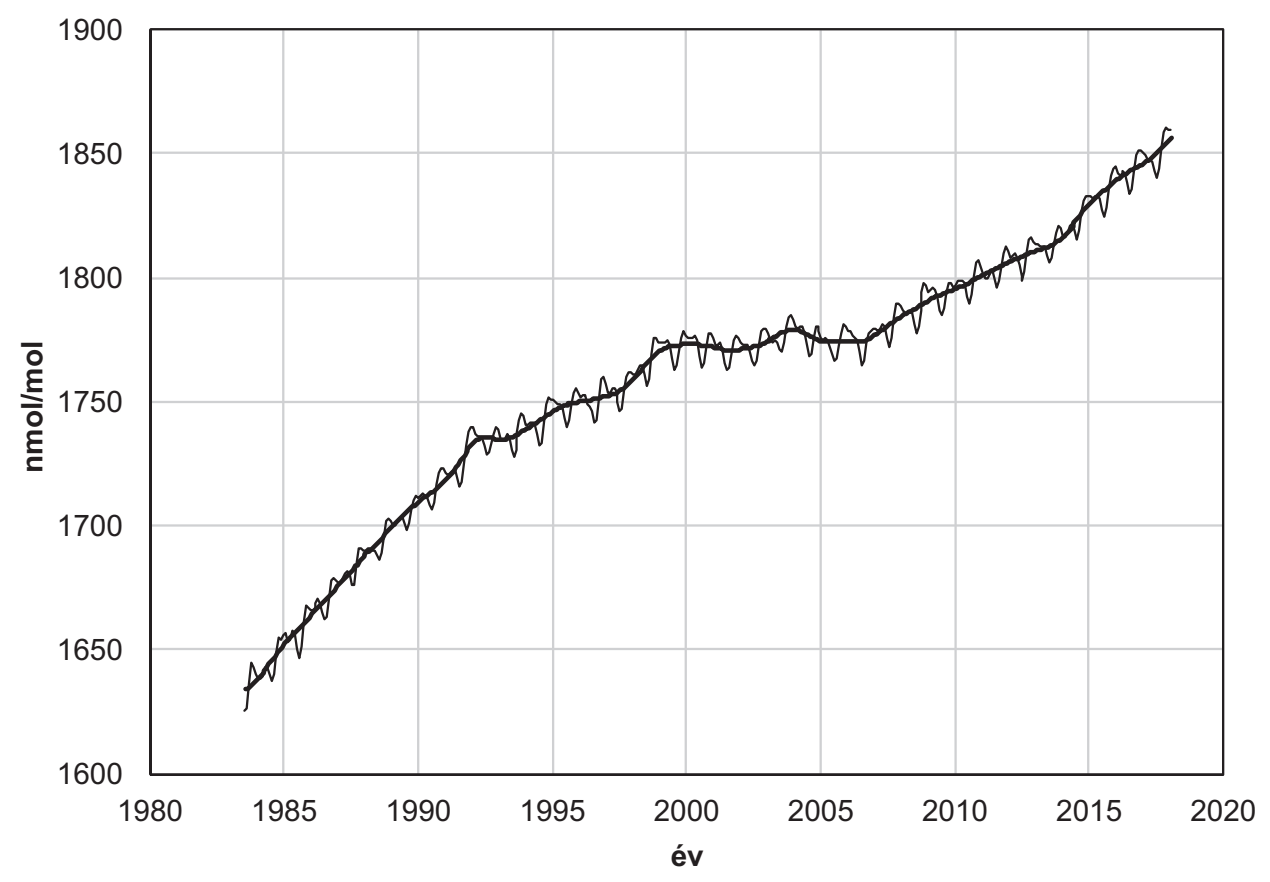

2. ábra. A metán globális havi légköri átlagkoncentrációja és a simított koncentrációmenet 1984től napjainkig (URL3)

ben növekedett, ami azt jelentette, hogy mintegy 30-35 Tg-mal több metán került évente a levegőbe, mint amennyi onnan távozni tudott. A növekedési ütem azonban fokozatosan lelassult, az 1990-es évek közepére stabilizálódott a koncentráció (eltekintve az 1997-1998-as El Niño időszaktól). Úgy tűnt, hogy a természeténél fogva koncentrációfüggő kémiai nyelő a koncentráció növekedésével végül egyensúlyba került az ez idő tájt a kelet-európai országok ipari megroppanásának hatására feltételezhetően megtorpanó antropogén kibocsátással. A források és a nyelők hozamára vonatkozó becslések nagyfokú bizonytalansága miatt tudományosan megalapozott álláspontot nem lehetett kialakítani. Környezetpolitikai okokból azonban megnyugtató volt azt hinni, hogy ha a szén-dioxid-koncentráció növekedését nem is sikerült megállítani, legalább a metáné megállt. Mintegy egy évtized elmúltával, 2006-2007-től azonban újraindult a metánkoncentráció emelkedése, és ma már ismét $10 \mathrm{nmol} / \mathrm{mol} /$ év körüli növekedést tapasztalunk (2. ábra). Ahogy a növekedés leállásának, úgy gyors ütemü újraindulásának sem volt, nincs kézenfekvő, könnyen belátható oka. Márpedig, ha nem tudjuk, hogy miért történik az, ami történik, akkor aligha tudunk megalapozott előrejelzéseket készíteni, felkészülni a várható következményekre, illetve mérsékelni a káros hatásokat. 


\section{A METÁNKONCENTRÁCIÓ NÖVEKEDÉSÉNEK LEHETSÉGES OKAI}

A forráshozamokra vonatkozó becslések bizonytalansága mellett a források és a nyelők között mostanra kialakult kb. 30 Tg/év mértékủ különbség eredetét nem lehet beazonosítani. Ráadásul a koncentráció növekedésében nemcsak a források erősödése, hanem a nyelök gyengülése is szerepet játszhat.

A fosszilis tüzelőanyagoknak az emelkedő szén-dioxid-koncentrációban is tükröződő növekvő felhasználása indokolhatja a metánkoncentráció emelkedését. Az izotóp-összetételre vonatkozó adatok azonban ezt nem igazán támasztják alá. Ha nő is a fosszilis eredetü metánkibocsátás, az alacsonyabb ${ }^{13} \mathrm{C} /{ }^{12} \mathrm{C}$-tartalmú metánkibocsátás növekedése ennél nagyobb. Ebbe a körbe pedig nemcsak a biológiai források tartoznak, hanem a melegedés hatására könnyen destabilizálódó, hatalmas mennyiségü „befagyott” metánt tároló metán-hidrát is.

A nagyrészt a sarkvidéki óceánokban a kontinentális talapzaton, részben a permafroszt régióban, de néhány más földrajzi körzetben is nagy mennyiségủ metán található metán-hidrát formájában, ami csak bizonyos hőmérsékleti és nyomásfeltételek mellett stabil. Fennáll a veszélye annak, hogy a különösen a sarkvidéki övezetben erős hőmérséklet-emelkedés hatására ennek a metánmennyiségnek egy része felszabadul, a légkörbe kerül, tovább erősítve a metán felszabadulásához vezető felmelegedést. Ez a metánkatasztrófa-forgatókönyv időről időre felbukkan a médiában. Jelenlegi tudásunk szerint azonban, ha teljesen kizárni nem is lehet ezt a forgatókönyvet, de nem is igazán valószínü. A metán-hidrát döntő része mélyen található, ahová a felszíni hőmérséklet-változás csak nagyon lassan jut el. Ennek következtében a destabilizálódás, a kibocsátás növekedése is csak nagyon lassú, évszázadokra, évezredekre elhúzódó lehet (Archer, 2007). Emberi időléptékben mérve éghajlati katasztrófát nem okozhat, de geológiai értelemben is hosszú időszakra fenntarthatja a jelenleginél erősebb légköri üvegházhatást, alapvetően megváltoztatva bolygónk képét. Az arktikus területek a melegedés hatására bizonyíthatóan egyre több metánt (és szén-dioxidot) bocsátanak ki, jelenleg azonban alapvetően a biológiai aktivitás erősödésének és nem a metán-hidrát destabilizálódásának hatására (Warwick et al., 2016).

Annak ellenére, hogy az arktikus területek metánkibocsátása a mérések szerint növekszik, a sarkvidéki és a trópusi területek közötti koncentráció-gradiens nem változik, azaz a trópusi területeken is nagyjából ugyanúgy nő a metánkibocsátás, mint a magasabb szélességeken (3. ábra). A metán stabilizotóp-adatai itt is a biológiai források dominanciáját mutatják. Származhat a metán a mezőgazdasági tevékenységből, a rizstermesztés és az állattenyésztés bővüléséből, de az utóbbi időben nedvesebbé váló trópusi területek növekvő metántermeléséből is. Mivel a mezőgazdasági tevékenységben, a légköri metánkoncentrációval ellentétben, ugrásszerü változások nem következtek be, többen a természetes eredetủ metánkibocsátás megnövekedését tartják valószínübbnek (Nisbet et al., 2016). 


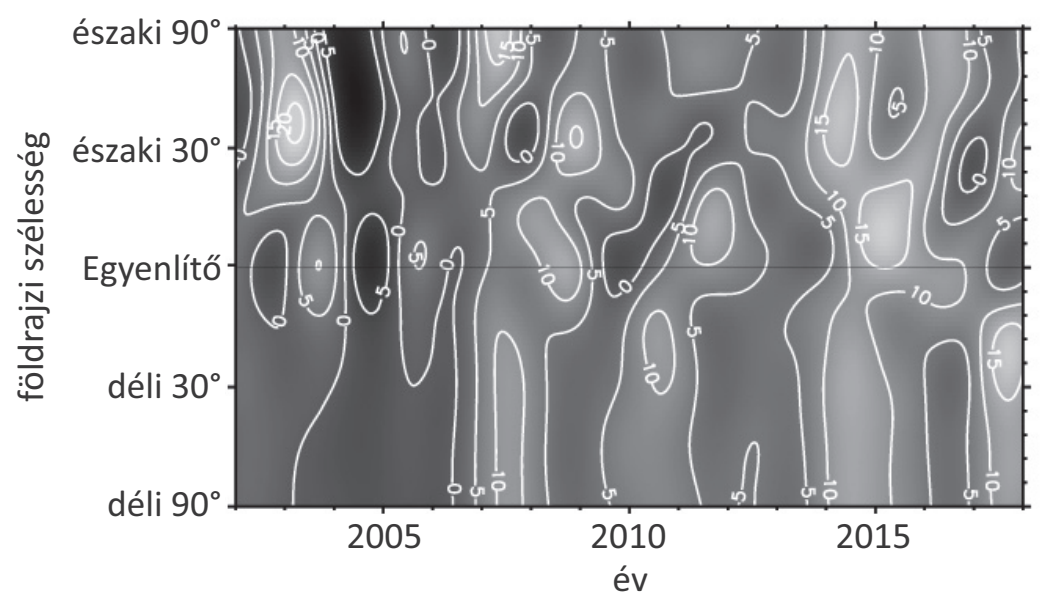

3. ábra. A légköri metánkoncentráció növekedési ütemének (nmol/mol/év) időbeli és földrajzi eloszlása a National Oceanic and Atmospheric Administration (USA) globális mérőhálózatának adatai alapján (Ed Dlugokencky, National Oceanic and Atmospheric Administration szívességéből)

A metánkoncentráció növekedésének megállását, majd újraindulását azonban a nyelőkapacitás egyidejü megváltozása is okozhatta. A metánt a légkörből kivonó hidroxil-gyök koncentrációját azonban rendkívül nehéz megmérni. Nagyon magas reaktivitása miatt légköri tartózkodási ideje csupán másodperces nagyságrendủ, koncentrációja pedig ezzel összhangban rendkívül alacsony, $10^{14} \mathrm{~mol} / \mathrm{mol}$ körül alakul. Mérni inkább csak közvetetten lehet, a jól ismert kibocsátású, gyakorlatilag kizárólag antropogén eredetü, szintén a hidroxil-gyökkel reagáló metil-kloroform légköri koncentrációjának alakulásán keresztül. Az ózonréteg védelmében hozott intézkedések ,árnyoldala", hogy a Montreali Jegyzökönyv a metil-kloroform gyártását is megtiltotta, aminek következtében légköri koncentrációja gyorsan csökken, egyre bizonytalanabbá téve a hidroxil-gyök mennyiségének becslését.

Matthew Rigby és munkatársai (2017) modellszámításaik alapján elképzelhetőnek tartják, hogy az antropogén szén-monoxid-kibocsátás 1990-es években megfigyelt csökkenése és a nitrogén-oxid-kibocsátás növekedése a kritikus időszakban a hidroxil-gyök koncentrációjának növekedését okozta, ami a metánkibocsátás folyamatos növekedése ellenére is a koncentráció stagnálásához vezetett. A 2000-es évek közepétől azonban a szén-monoxid és a nitrogén-oxid kibocsátásában már nem volt lényeges változás, így megszünt a hidroxil-gyök koncentrációjának növekedése, a növekvő metánkibocsátás mellett pedig újra növekedésnek indult a metánkoncentráció. A hidroxil-gyök koncentrációjának számított változása azonban belül maradt a modell bizonytalansági tartományán, sőt 
a bizonytalansági tartományba még az is belefér, hogy csökkenő metánkibocsátás mellett is nőhetne a metán légköri koncentrációja (Turner et al., 2017).

A légköri metánmérleg korszerü modelljei nagymértékben támaszkodnak a különböző típusú forrásokból származó metán jellemző stabilizotóp-összetételére. Az egyes forrástípusokon belül a különböző forrásokból származó metán stabilizotóp-összetétele azonban nem teljesen azonos. Az eltérő takarmányozás miatt valamelyest más a trópusi és a mérsékelt égövi állattenyésztés során történő metánkibocsátás stabilizotóp-összetétele, és ugyanez érvényes a különböző földrajzi-geológiai körzetek fosszilis eredetủ (például szénbányászat) és természetes bioszferikus (például mocsarak) metánkibocsátására is. A kibocsátási területek dominanciájának változása némileg módosítja az adott forrástípusra vonatkozó átlagos izotóp-összetételt, amit a modellek csak akkor tudnának követni, ha folyamatosan részletes mérési adatok állnának rendelkezésre (Feinberg et al., 2018). A stabilizotóp-mérések azonban mindmáig rendkívül ritkák.

Rona Thompson és munkatársai (2018) számításaik alapján úgy vélik, a koncentrációnövekedést eredményező többletmetán 1/3-2/3 arányban származhat a fosszilis tüzelőanyagok továbbra is növekvő felhasználásából, illetve biológiai forrásokból. Továbbfejlesztett inverz terjedési modelljük is megerősíti, hogy jelenleg a biológiai eredetủ többletmetán zöme a trópusi területekről kerül a levegőbe, de változatlanul tisztázatlan, hogy ebben mekkora az ember közvetlen szerepe, illetve mekkora az általa gerjesztett éghajlatváltozásé.

Mivel a metánkoncentráció változását csak viszonylag rövid időszakon tudjuk tanulmányozni, azt sem zárhatjuk ki teljesen, hogy egyszerüen az éghajlat természetes ingadozása gerjeszti az emberi tevékenység okozta növekedésre rakodó ingadozásokat. Nehezíti a megértést, hogy valószínüleg számos, részben esetleg egymással ellentétes hatású folyamat eredő hatását látjuk.

\section{KÖVETKEZTETÉSEK}

A metán okozta energetikai (sugárzási) kényszer harmada a szén-dioxidénak $\left(0,61 \mathrm{~W} / \mathrm{m}^{2}\right.$, illetve $1,83 \mathrm{~W} / \mathrm{m}^{2}$ - Etminan et al., 2016), azaz nem elhanyagolható. Légköri tartózkodási ideje viszonylag rövid, ezért utánpótlásának csökkenése esetén koncentrációja és energetikai hatása is belátható időn belül lecsökkenne. A metánkoncentráció jövőbeni változása érdemben kihathat az éghajlat alakulására. A témakörben megjelenő tanulmányok egyhangúlag leszögezik, hogy több mérésre, több adatra van szükség ahhoz, hogy megalapozott képet kaphassunk a légköri metánnal kapcsolatos folyamatokról, és így becsülni lehessen a várható változásokat (Prather-Holmes, 2017; Turner et al., 2017). Meglévő tudásunk alapján csak valószínűsíthető, hogy a jelenlegi növekedés nagyobb részét a biológiai eredetủ metán okozza. Ha ebben a mezőgazdaság, az állattenyésztés játszik meg- 
határozó szerepet, akkor elvileg módunk van beavatkozni a kibocsátás csökkentése érdekében, bár az élelmiszer-ellátás biztonságának fenntartása mellett ez nem lenne egyszerü feladat. Lényegesen rosszabb a helyzet, ha a természetes biológiai folyamatok hajtják a légköri metánkoncentráció emelkedését. Ebben az esetben ugyanis pozitív visszacsatolással állunk szemben, amelyben a már bekövetkezett éghajlatváltozás serkenti a további éghajlatváltozást okozó metánkibocsátás erősödését, azaz a természet magához ragadja az éghajlat szabályozását, kiszolgáltatottá téve a nem kellő körültekintéssel tevékenykedő emberiséget. Alapos okunk van tehát arra, hogy a tudományos kutatásban kiemelt figyelmet szenteljünk az üvegházgáz-ranglista második helyezettjének is.

\section{IRODALOM}

Archer, D. (2007): Methane Hydrate Stability and Anthropogenic Climate Change. Biogeosciences, 4, 521-544. DOI: 10.5194/bg-4-521-2007

Bergamaschi, P. - Karstens, U. - Manning, A. J. et al. (2018): Inverse Modelling of European $\mathrm{CH}_{4}$ Emissions during 2006-2012 Using Different Inverse Models and Reassessed Atmospheric Observations. Atmospheric Chemistry and Physics, 18, 901-920. DOI: 10.5194/acp-18-901-2018

Etminan, M. - Myhre, G. - Highwood, E. J. et al. (2016): Radiative Forcing of Carbon Dioxide, Methane, and Nitrous Oxide: A Significant Revision of the Methane Radiative Forcing. Geophysical Research Letters, 43, 12,614-12,623. DOI: 10.1002/2016g1071930

Feinberg, A. I. - Coulon, A. - Stenke, A. et al. (2018): Isotopic Source Signatures: Impact of Regional Variability on the $\delta^{13} \mathrm{CH}_{4}$ Trend and Spatial Distribution. Atmospheric Environment, 174, 99-111. DOI: 10.1016/j.atmosenv.2017.11.037

Ferretti, D. F. - Miller, J. B. - White, J. W. C. et al. (2005): Unexpected Changes to the Global Methane Budget over the Past 2000 Years. Science, 309, 1714-1717. DOI: 10.1126/science.1115193

Houweling, S. - Bergamaschi, P. - Chevallier, F. et al. (2017): Global Inverse Modeling of $\mathrm{CH}_{4}$ Sources and Sinks: An Overview of Methods. Atmospheric Chemistry and Physics, 17, 235256. DOI: 10.5194/acp-17-235-2017

Kirschke, S. - Bousquet, P. - Ciais, P. et al. (2013): Three Decades of Global Methane Sources and Sinks. Nature Geoscience, 6, 813-823. DOI: 10.1038/ngeo1955

Loulergue, L. - Schilt, A. - Spahni, R. et al. (2008): Orbital and Millennial-scale Features of Atmospheric $\mathrm{CH}_{4}$ over the Past 800,000 Years. Nature, 453, 383-386. DOI: 10.1038/nature 06950

Migeotte, M. V. (1948): Spectroscopic Evidence of Methane in the Earth's Atmosphere. Physical Review, 73, 519-520. DOI: 10.1103/PhysRev.73.519.2

Monteil, G. - Houweling, S. - Dlugockenky, E. J. et al. (2011): Interpreting Methane Variations in the Past Two Decades Using Measurements of $\mathrm{CH}_{4}$ Mixing Ratio and Isotopic Composition. Atmospheric Chemistry and Physics, 11, 9141-9153. DOI: 10.5194/acp-11-9141-2011

Nisbet, E. G. - Dlugokencky, E. J. - Manning, M. R. et al. (2016): Rising Atmospheric Methane: 2007-2014 Growth and Isotopic Shift. Global Biogeochemical Cycles, 30, 1356-1370. DOI: $10.1002 / 2016 \mathrm{gb} 005406$

Prather, M. J. - Holmes, C. D. (2017): Overexplaining or Underexplaining Methane's Role in Climate Change. Proceedings of the National Academy of Sciences of the USA, 114, 5324-5326. DOI: $10.1073 /$ pnas. 1704884114 
Quay, P. - Stutsman, J. - Wilbur, D. et al. (1999): The Isotopic Composition of Atmospheric Methane. Global Biogeochemical Cycles, 13, 445-462. DOI: 10.1029/1998GB900006

Rigby, M. - Montzka, S. A. - Prinn, R. G. et al. (2017): Role of Atmospheric Oxidation in Recent Methane Growth. Proceedings of the National Academy of Sciences of the USA, 114, 53735377. DOI: $10.1073 /$ pnas. 1616426114

Sapart, C. J. - Monteil, G. - Prokopiou, M. et al. (2012): Natural and Anthropogenic Variations in Methane Sources during the Past Two Millennia. Nature, 490, 85-88. DOI: 10.1038/nature11461

Saunois, M. - Bousquet, P. - Poulter, B. et al. (2016): The Global Methane Budget 2000-2012. Earth System Science Data, 8, 697-751. DOI: 10.5194/essd-8-697-2016

Thompson, R. L. - Nisbet, E. G. - Pisso, I. et al. (2018): Variability in Atmospheric Methane from Fossil Fuel and Microbial Sources over the Last Three Decades. Geophysical Research Letters, 45, 11499-11508. DOI: 10.1029/2018GL078127, https://agupubs.onlinelibrary.wiley.com/ doi/10.1029/2018GL078127

Turner, A. J. - Frankenberg, C. - Wennberg, P. O. et al. (2017): Ambiguity in the Causes for Decadal Trends in Atmospheric Methane and Hydroxyl. Proceedings of the National Academy of Sciences of the USA, 114, 5367-5372. DOI: 10.1073/pnas.1616020114

Warwick, N. J. - Cain, M. L. - Fisher, R. et al. (2016): Using $\delta 13 \mathrm{CCH} 4$ and $\delta \mathrm{D}-\mathrm{CH} 4$ to Constrain Arctic Methane Emissions. Atmospheric Chemistry and Physics, 16, 14891-14908. DOI: 10.5194/acp-16-14891-2016

URL1: http://digital.onb.ac.at/OnbViewer/viewer.faces?doc=ABO_\%2BZ198303202

URL2: ftp://ftp.ncdc.noaa.gov/pub/data/paleo/icecore/antarctica/law/law2006.txt

URL3: https://www.esrl.noaa.gov/gmd/ccgg/trends_ch4 